\title{
Research on the Relationship of Government subsidies and Enterprise performance
}

\author{
Hongyan Yan ${ }^{1, a^{*}}$ Yaning $\mathrm{Li}^{1, \mathrm{~b}}$ \\ ${ }^{1}$ Management College , Beijing Union University, Beijing, China \\ ${ }^{2}$ Management College , Beijing Union University, Beijing, China \\ ayanhy819@126.com \\ bgltyaning@buu.edu.cn \\ ${ }^{*}$ Corresponding author
}

Keywords: Government subsidies; Enterprise performance; Tax preferences

\begin{abstract}
As for emerging market economies with imperfect market mechanism, the guiding role of government in the development and innovation of SMEs is very necessary. This paper selects listed companies on GEM between 2012 to 2014 as analysis objects and multivariate regression model has been applied to study the impact of government policies of science and technology on the R\&D and innovation performance of SMEs. The results have showed that: direct government subsidies has eased the financial pressure on businesses, which can facilitate the improvement of business performance; government policies to adopt reduction and exemption or tax refund for enterprises can facilitate the $\mathrm{R} \& \mathrm{D}$ and innovation performance of enterprises. Finally, the article has further analysis of the causes and the corresponding countermeasures to address these issues.
\end{abstract}

\section{Introduction}

Fiscal subsidy is a kind of compensation provided to businesses or individuals in order to achieve specific political, economic and social goals. Government subsidy is a common way of of government resource allocation, and its main purpose is to support or encourage the development of certain areas, specific industries or fields, and create a better environment for local employment. According to public Wind data and information, as of the first half of 2014, semi-annual report has showed that a total of 2235 listed companies enjoy government subsidies and government subsidies are up to a total of 32.263 billion yuan, and the number of listed companies that have enjoyed government subsidies account for $88.1 \%$ in the listed companies disclosed in the first half. With increasing of government subsidies, we have to re-examine the impact of government subsidies to the enterprise. In this paper, the listed companies on GEM have been regarded as samples, the empirical study has been conducted on the impact of government subsidies on the performance of SMEs, in order to provide empirical evidence to evaluate the effectiveness of micro-level government policy.

\section{Literature review and research hypothesis}

Currently, the government subsidy has become common in many domestic and foreign countries to support and encourage the development of certain enterprises or industries, including government direct monetary subsidies and special indirect subsidies through tax deduction and exemption or incentives.

Research results of Sourafel Girma (2006) have indicated that the Northern Ireland government subsidies not only can effectively help companies get rid of financial difficulties, but also can improve operational efficiency and enhance research and development capabilities. Zhang Liqin, Lin Wanlong and Peng Yi (2009) have measured the business performance by virtue of business profitability without 
considering the long-term performance of enterprises, and direct government subsidies may affect the current net profit of enterprises and improve the net profit to some degree. Wang Yihui (2013)has taken the effect of subsidy income on the innovation performance of enterprises into consideration and found that the relationship between the two is positive. Tan Jian (2014) has studied the impact of public subsidies to business performance, and the results have shown that it plays a stimulating and incentive function. Kong Dongmin and Li Tianshang(2014)have conducted research on whether government subsidy can improve business performance and social responsibility, and the research result has shown that government subsidies have positive effect on the enhancement of the company's performance and social responsibility. A possible drawback caused by government subsidies is that some companies are overly dependent on government subsidies, and the subsidies serve only to make up for the loss of enterprises, leading to the company's low productivity and declining operating performance. However, with the gradual improvement of the follow-up monitoring mechanism in recent years, general subsidies are reduced gradually, and the proportion of subsidies for special projects are increased, so that the original intention of government subsidies have been realized step by step. Direct government subsidies are direct injections of corporate funds, which can reduce the pressure on corporate finance, so that enterprise solvency and investment ability can be improved to some extent; in addition, enterprises have sufficient funds for $\mathrm{R} \& \mathrm{D}$ and innovation to promote enterprise performance.

Hypothesis 1: government subsidies have a positive role in promoting enterprise performance.

Tax incentives is another kind of government subsidies, which is not only a form of indirect subsidies and a means of finance and tax subsidy through the tax relief policy, but also can give great encouragement to the enterprise's production and development. Government tax incentives given to companies can be divided into three main aspects. The first is the direct tax rate concession, in order to guide and encourage the development of certain industries and regions and improve the level of GDP of its industries and regions, the government will give some support directly on the tax rate. The second is the tax return, which refers to that enterprises pay taxes according to normal corporate tax rate to the tax authorities and partial funds will be returned as tax subsidies after the tax authorities or relevant departments have reviewed in accordance with relevant laws and regulations. The third is the value-added tax preferential policies, namely the tax reduction or tax exemption.

For example, the enterprises whose monthly income is no more than 30,000 yuan and small-scale taxpayers can enjoy preferential policies to exempt from VAT. According to research done by Jiang Jing (2011) at the district level and industry level, tax incentives plays a role in enhancing business performance. Ren Zengrui (2011)has conducted an analysis through linear regression model, and results (1)show that income tax incentives have positive correlation with performance of SMEs; (2) value-added tax concessions can promote the investment capacity of SMEs. Tax incentives are an indirect way of government subsidies to business, which encourages the development of certain industries and regions to a certain extent, so that business performance can be improved.

Hypothesis 2: tax incentives has a positive role in promoting enterprise performance.

\section{Research study}

Research model and variable.After analyzing the impact of direct government subsidies and tax incentives on business performance from domestic and foreign scholars, the explained variable in the article refers to that ROE is selected as the indicator of the corporate performance, explainatory variable refers to that tax rate and government subsidy strength actually obtained by enterprises are used to measure tax incentives and direct government subsidies respectively, as for the selection of the control variables, the paper selects such 3 indicators as solvency, business size and industry to establish model for analysis of the relationship between government subsidies and corporate performance, the study model (1 ) is to verify the relationship between direct government subsidies and 
corporate performance, study model (2) is to verify the relationship between tax incentives and corporate performance.

$$
\begin{aligned}
& \mathrm{ROE}=\alpha_{0}+\alpha_{1} \text { Subsidy }+\alpha_{2} \text { Controls }+\varepsilon \\
& \mathrm{ROE}=\beta_{0}+\beta_{1} \text { Etr }+\beta_{2} \text { Controls }+\varepsilon
\end{aligned}
$$

At present, most scholars use one of market indicators, financial indicators and TFP as a indicator to measure corporate performance, and financial indicators include return on equity, per share net profit margin, return on assets, and market indicators use Jensen ALPHA, Tobin's Q and Sharpe indicators to measure business performance. Return on equity (ROE) is an important and the most comprehensive financial indicator to measure the profitability of the enterprise, which ranks in the first place for listed companies, therefore, the indicator has been applied as the explained indicator in the paper to the level of performance. In addition, the paper also chooses the government subsidy strength as the indicator of measuring direct government subsidy for enterprises, which is defined as the ratio between government subsidy income and total operating income (total of main business income and other operating income and operating income). Tax rate obtained by enterprises is regarded as another explanation variable to measure tax incentives. We also select such three indicators as firm size (Size), enterprise solvency, namely assets and liabilities ratio (Debt) and Industry (Industry) as control variables to conduct correlation test for explanatory variables. Relevant variables are defined in Table 1.

Table 1 Variable definition table

\begin{tabular}{l|l|l|l}
\hline variable & variable name & $\begin{array}{l}\text { variable } \\
\text { symbol }\end{array}$ & variable definition \\
\hline $\begin{array}{l}\text { exlained } \\
\text { variable }\end{array}$ & ROE & ROE & $\begin{array}{l}\text { ratio of corporate net margin in net asset } \\
\text { the higher the ratio, the higher the performance } \\
\text { level caused by subsidy. }\end{array}$ \\
\hline $\begin{array}{l}\text { explanatory } \\
\text { variable }\end{array}$ & $\begin{array}{l}\text { government } \\
\text { subsidy strength }\end{array}$ & Subs & $\begin{array}{l}\text { percentage of subsidy income in gross operating } \\
\text { income } \\
\text { to measure direct government subsidy. }\end{array}$ \\
\hline $\begin{array}{l}\text { corporate } \\
\text { preferential tax } \\
\text { rate }\end{array}$ & Etr & $\begin{array}{l}\text { to measure tax incentives and introduce } \\
\text { dummy variable } \\
\text { when tax rate is 25\%, dummy varibale is 0, and } \\
\text { other dummy varibales are 1. }\end{array}$ \\
\hline variable & enterprise size & Size & \begin{tabular}{l} 
natural logarithm of total corporate asset \\
\hline
\end{tabular} \\
\hline & $\begin{array}{l}\text { enterprise } \\
\text { solvency }\end{array}$ & Debt & $\begin{array}{l}\text { namely corporate asset-liability ratio, } \\
\text { Percentage of total liabilities in total assets }\end{array}$ \\
\hline
\end{tabular}

Source of sample and data.In this paper, 446 listed companies on GEM between 2012 to 2014 have been selected as sample data, in order to ensure the validity of data, the paper excludes ST, * ST, listed companies on suspension and delisting companies and also excludes deficient data sample and irration data. 249 sample data can be obtained for 83 sample companies through the manual screening of the normally listed companies for three consecutive years between 2012 to 2014. Data in the article comes from CSMAR. 
The empirical result analysis for the impact of government subsidy on corporate performance Descriptive statistical analysis .

Table 2 Descriptive statistics

\begin{tabular}{l|l|l|l|l|l}
\hline & $\begin{array}{l}\text { observed } \\
\text { value }\end{array}$ & $\begin{array}{l}\text { minimal } \\
\text { value }\end{array}$ & $\begin{array}{l}\text { maximal } \\
\text { value }\end{array}$ & mean value & $\begin{array}{l}\text { standard } \\
\text { deviation }\end{array}$ \\
\hline ROE & 249 & 0.0034 & 0.3049 & 0.0926 & 0.0549 \\
\hline Size & 249 & 8.5855 & 9.7433 & 9.0299 & 0.2301 \\
\hline Debt & 249 & 0.0140 & 0.6499 & 0.2312 & 0.1390 \\
\hline Subs & 249 & 0.0000 & 0.1083 & 0.0157 & 0.0210 \\
\hline Etr & 249 & 0 & 1 & 0.5677 & 0.4405 \\
\hline Ind & 249 & 0.1084 & 0.2409 & 0.1667 & 0.2197 \\
\hline
\end{tabular}

Table 2 shows the descriptive statistics of the variables, we can see that the standard deviation for government subsidies strength is 0.0229 , and the mean value is 0.0158 , and standard deviation is higher than the mean value, which explains the average proportion of government subsidies obtained by sample companies in total operating revenue is not high and there is a large difference in subsidy strength received between sample companies, the overall level of the company scale is larger, and the overall average level of asset-liability ratio is lower. Thus, direct government subsidies for sample companies is not enough, and from the perspective of the tax rate obtained by business, there are more than $85 \%$ of the sample companies enjoy the corporate tax incentives more or less, indicating the government subsidies on preferential tax policies are larger.

Table 3 Government subsidies of different years

\begin{tabular}{|c|c|c|c|c|c|c|c|}
\hline & $\begin{array}{l}\text { average } \\
\text { ROE }\end{array}$ & $\begin{array}{l}\text { number of } \\
\text { samples } \\
\text { receiving } \\
\text { government } \\
\text { subsidies }\end{array}$ & $\begin{array}{l}\text { percent } \\
\text { age }\end{array}$ & $\begin{array}{l}\text { mean } \\
\text { value (ten } \\
\text { thousand } \\
\text { yuan) }\end{array}$ & $\begin{array}{l}\text { number of } \\
\text { samples } \\
\text { receiving } \\
\text { preferential } \\
\text { tax rate }\end{array}$ & $\begin{array}{l}\text { percent } \\
\text { age }\end{array}$ & $\begin{array}{l}\text { mean } \\
\text { value } \%\end{array}$ \\
\hline 2012 & 0.0841 & 55 & 66.27 & 859.47 & 66 & 79.52 & 15.00 \\
\hline 2013 & 0.0844 & 62 & 74.7 & 1035.95 & 67 & 80.72 & 14.92 \\
\hline 2014 & 0.0965 & 65 & 78.31 & 1074.14 & 69 & 80.13 & 14.64 \\
\hline
\end{tabular}

Table 3 is the analysis for data in diferent years, we can see government subsidies between 2012 to 2014 are increased year by year, and the number of samples receiving government subsidies samples is 55,62 and 65 respectively, and the mean value has been increased from 8.5947 million in 2012 yuan to 10.7414 million yuan in 2014, and the number of samples receiving government subsidies has been increased from 66 in 2012 to 68 in 2014, and the mean preferential tax rate is decreasing year by year, that is to say government tax incentives for enterprises also increase year by year, and this corresponds to that ROE has been increased from 0.0841 to 0.0965 , from the above analysis, the basic trend can be seen, along with the continuous increase of government subsidies, corporate business performance shows a gradual increasing trend; with the greater degree of government preferential tax rates, the level of corporate performance is gradually improving. 


\section{Correlation analysis}

In order to ensure the accuracy of the conclusions, it is necessary to conduct correlation test for the main variables selected in the research model, and the paper uses SPSS software to conduct Pearson correlation [2] two-sided test for the selected variables. The results show that firm size (Size), government subsidies intensity (Subsidy) and return on equity (ROE) have showed a significant correlation at the 0.01 level, and Pearson correlation coefficient is below 0.4 between the selected variables inmodel, indicating that there is no multi-linear relationship between the multiple variables of the above model, it is feasible.

Liner-regression analysis for the impact of government subsidies on corporate performance .As for the regression analysis for the model (1) and model (2) in table 4, we can see that the coefficient of government subsidy strength and tax incentives as well as corporate performance are all positive, and the significance level corresponding to all the variables is below 0.05 or less, thus, we can conclude that the government's direct subsidies and tax concessions and ROE were positively correlated, which can be drawn that direct government subsidies and tax incentives have positive correlation with enterprise performance.

Table4. Estimation Result

\begin{tabular}{l|l|l}
\hline & MOD(1) & MOD $(2)$ \\
\hline Subs & $2.730 * * *$ & \\
\hline Etr & & $0.754 * *$ \\
\hline Size & $2.779 * * *$ & $2.908^{* * *}$ \\
\hline Debt & $-1.170^{* *}$ & $-1.003^{* *}$ \\
\hline dum_Indu1 & $-0.1933 * * *$ & $-0.0814 * *$ \\
\hline dum_Indu2 & $0.0830^{* *}$ & $0.0860^{* *}$ \\
\hline dum_Indu4 & $0.1026^{*}$ & $0.1084 *$ \\
\hline dum_Indu4 & $0.0012^{* *}$ & $0.0010^{* *}$ \\
\hline cons & $-2.147 * *$ & $-2.350^{* *}$ \\
\hline r2_a & 0.3162 & 0.1827 \\
\hline $\mathrm{N}$ & 249 & 249 \\
\hline F value & $39.98 * * *$ & $18.54 * * *$ \\
\hline legend:*p<.1; $* * \mathrm{p}<.05 ; * * * \mathrm{p}<.01$ & \\
\hline
\end{tabular}

Robustness test .To ensure the accuracy of the drawn conclusions, the paper selects return on assets (ROA) financial indicators to conduct robustness test for the memory model of selected samples, and direction and significance levels of the main explanatory variables have no significant changes, which are consistant with original regression results, indicating that the measurement regression results in the paper are robust. The above has further confirmed the government's direct subsidies and tax incentives can facilitate the production and management performance of enterprises.

\section{Summary}

In this paper, 83 listed companies on GEM between 2012 to 2014 have been selected as samples in the paper to conduct the empirical analysis for the impact of direct government subsidies and tax incentives on enterprise performance, the following conclusions can be drawn:

First, direct government subsidies and business performance are positively correlated. According to yearly analysis between 2012 to 2014 , government subsidies increase year by year, while its corresponding business performance are increasing year by year, which indicates that direct government subsidies is a very effective means of reducing the pressure on corporate financing and stimulating the production and management performance of enterprises under China's current market 
economy, indicating direct government subsidies play an effective role in facilitating business performance.

Second, tax incentives can promote enterprise production and management performance. Through the comparison between the enterprises that have obtained tax incentives and enterprises that haven't obtained tax incentives between 2012 to 2014, tax incentives can stimulate business performance.

\section{Acknowledgement}

This paper is funded by Institute of Beijing Studies , National-sponsored Social Sciences Funding Program:14BGL034, Humanities and Social Science Research Project of Chinese Ministry of Education "Sustainable Development Research of Micro-credit Based on the Perspective of welfare"(13YJC790084) 。

\section{References}

[1]Wang Suikun, Hao Jiwei .Research on the Relationship of Government Funding Tax Policy and Technological Innovation--Based on Urowth Enterprise Market Empirical Evidence. Science\&Technology Progress and Policy. 2014(5)92-96

[2]Gonzlez. Do public subsidies stimulate private R\&D spending. Research Policy, 2008(37):371-389.

[3]Bloom ENEN. Do R\&D tax credits work? evidence from a panel of countries 1979-1997.Journal of Public Economics.2002.85(3):1-31.

[4] Tzelepie,Skurae. The effects of Regional Capital Subsidies on Finn Performance; an Empirical study. Joturul of Small Business and Enterprise Development.2004 (11)121-129.

[5] Bergstrom F. Capital subsidies and the Performer of firms. Small business economics , 2000 (14) 183-193.

[6]Sourafel Girma .New Ventures and their Credit Terms. Small Business Economics, 2006(26 )

$351-364$

[7]Anwar Sanusi,Tatsuo Oyama. Statistical data analysis for investigating Japanese government subsidy policy for private universities. Higher Education, 2008,.55 (4) 407-423

[8]Zhiying Liu,Qinqin Li.The Government Subsidy Strategy Choice for Firm's R\&D: Input Subsidy or Product Subsidy?Udo Broll Economics Research International 2014 (23)110-119

[9] Wang Wenhua,Xia Dandan, Zhu Jiaxiang .Empirical Research on Mitigation of Government Subsidies on Financing Constraints of Research and Development Investment:Empirical Evidence from Public Company of High and New Technology Science\&Technology Progress and Policy.2014(4)22-26 